\title{
Analysis of resource potential for cattle developing in Serdang Bedagai regency
}

\author{
M Iqbal, E Mirwandhono, T H Wahyuni, N Ginting, I Sembiring \\ Animal Production Program Study, Faculty of Agriculture,University of North \\ Sumatera. \\ Medan 20155,Indonesia \\ E-mail: nurzainahginting@gmail.com
}

\begin{abstract}
High animal production especially meat is still need to fulfilled as demand is high. This research was conducted to analyze the availability of resources in Serdang Bedagai Regency in the context of cattle developing. The study was conducted from September 2017 to January 2018. This study used a survey method, the first stage of stratification (stratified sampling) to the sub-districts in Serdang Bedagai Regency, the second stage took purposive sampling in three sub-districts namely Dolok Masihul District, Dolok Merawan and Sei Rampah, the third stage was purposively sampling of 10 farmers from each of the subdistricts. The results of this study that livestock resources in Serdang Regency Bedagai still have great potential in developing beef cattle business seen from natural resources, human resources, capital and technology.
\end{abstract}

\section{Introduction}

Efforts to accelerate beef self-sufficiency through two strategies in 2014 pursued the strategy of technical and non-technical. Technical strategy includes: 1) the development of breeding and fattening centers using assisted reproductive technologies (artificial insemination and natural mating with a male superior) in the area of development of beef cattle; 2) revitalisas institutional and human resources in the field by reactivating Post IB, Poskeswan, provides equipment and infrastructure required; and 3) strengthening of infrastructure and facilities in the form of pasture land, creation of ponds, feed processing equipment, facilities services unit IB and other necessary facilities.

Serdang Bedagai is one area the deployment of the livestock population in North Sumatra that have the potential for the development of the cattle population. Because the region include cow cattle population growth in 2013 reached44 825 tail

\section{Materials and Methods}

\subsection{Time and place of study}

This study was conducted in Serdang North Sumatra province Bedagai namely Kecamtan Dolok Masihul, District Dolok Merawan and Sei Rampah of a total of 17 sub-district due to start in September 2017 until January 2018.

This study population is farmers in Serdang Bedagai, first put through stratification (stratified sampling) divided into three groups of sub-district with a high population of beef cattle, beef cattle population were, beef cattle population is low. Both take intentionally (purposive sampling) three subdistricts Dolok Masihul, District Dolok Merawan and Sei Rampah. All three take intentionally (purposive sampling) 10 farmers from each district elected. 


\subsection{Data analysis}

The primary data obtained directly from the monitoring of respondents to the beef cattle business activities through interviews and questionnaires, secondary data obtained from various related agencies such as the Office of National Statistics Agency and Department of Livestock Serdang Bedagai. Step, that in this study is used to describe the state of the power source beef cattle farms in the region Bedagai Serdang.

\section{Results and Discussion}

\subsection{An Overview of Research Sites}

Serdang Bedagai is one of the districts in North Sumatra, East Coast region. In astronomical Bedagai Serdang located at 03 01'2,5 " North - 03 46'33 " North latitude and 98 44'22 " East longitude - 99 $19^{\prime} 01$ " East Longitude with an altitude ranging from 0-500 meters above sea level. Serdang Bedagai has an area of $1900.22 \mathrm{~km} 2$ which consists of 17 districts and 237 villages, and 6 villages. Most districts that area is the District Dolok Masihul is $237.42 \mathrm{~km} 2$ or 12.49 percent of the Serdang Bedagai. Most small districts that is District of Serbajadi is $50.69 \mathrm{~km} 2$ or 2.67 percent of the Serdang Bedagai.

\subsection{Land, Water and Genetic Resources.}

UU Peternakan dan Kesehatan Hewan (2009), In order to ensure certainty of implementation of animal husbandry and health required the provision of land that meets the technical requirements of livestock and animal health. In Table 4 producer of grass land in Serdang Bedagai area of 50034.01 hectares. While agricultural waste-producing land consists of 3476 hectares of land producing corn, rice 75422 hectares, 13406 hectares of cassava, yams $15 \mathrm{Ha}$, Ha 8 peanuts, soybeans $583 \mathrm{Ha}$, Ha 219 Green Peas., Water resources in Serdang Bedagai relatively large when seen from the many rivers that flow through the region. Water resources in Serdang Bedagai generally spread in every district.

The study states that all farmers use well water for livestock drinking water and given routinely every day. By providing drinking water to cattle on a regular basis, it will reduce the death rate of cattle due to lack of drinking water. In addition to the need to drink, water is also needed to bathe cattle.

Nation cows contained in Serdang Bedagai is Brahman, Peranakan Ongole (PO), Simental and Limousin. Livestock in Serdang Bedagai IB are already using the technology. The cement used for the IB imported from Lembang and BIB BIB Singosari.

\subsection{Human Resources}

Table 1. The level of education, experience, age and job breeders.

\begin{tabular}{llll}
\hline Level of education & Raising experience & age Breeders & Work \\
\hline SD $(37 \%)$ & $<5$ years $(56 \%)$ & $31-40(36 \%)$ & Farmers $(53 \%)$ \\
SMP $(46 \%)$ & 6-10 years $(26 \%)$ & $41-50(46 \%)$ & Employees $(13 \%)$ \\
SMA (16\%) & 11-20 years $(13 \%)$ & $>51(16 \%)$ & Labor $(13 \%)$ \\
& $>21$ Years $(3 \%)$ & & Traders $(3 \%)$ \\
& & & Breeders $(10 \%)$ \\
& & Self-employed (6\%) \\
\hline
\end{tabular}

Source: Breeders (Results of secondary data processing 2018).

Can be seen in Table 1. The majority of farmers educational level (46.6\%) and amounted to junior high school graduation (37.6\%) completed primary school education level is still relatively low. The level of education will affect the performance of the breeder, this is related to patterns of thought and work systems. The higher the education level, the more farmers can adapt to technological developments and increase efficient ways of thinking. In Table 1 shows the experiences of farmers ranges between 1-30 years, the general experience is still new breed as many as many as 17 farmers've been raising for 1-5 years (57\%). It is not mengahambat farmers in business. Age is a determinant of potential breeders because it determines the resulting performance and productivity. In Table 1. Age farmers ranged between 30-62 years. Age farmers in Serdang Bedagai majority (84\%) 
are in the productive age range is between 31-50 years. While farmers are in the age range of unproductive $>51$ years as much as $17 \%$. The age range $31-40$ years is very good because at the age of productive farmers have physical conditions and the ability to think is good, so it is still possible for breeders to improve the skills and knowledge to maintain both beef cattle.

\subsection{Natural Resources, Technology and Capital}

The spread of cattle in each of the districts is uneven, there are some highly populated areas, there are, but there are very rare or limited population. Some of the factors that cause inequities among other factors livestock population of agricultural and population density, climate and social customs. Search edged farming communities can not be separated from the cattle business, both for power, fertilizer, or others in the framework of the processing of agricultural land. Cattle during this depends also on agriculture, because of their more advanced farming means it will support the production of animal feed forage, agricultural byproduct in the form of grain or feed amplifier that everything needed by a cow.

Mechanical maintenance of the farm in Serdang Bedagai in general still have traditionally earned. This can be seen from raising cattle like cage, equipment used, disease prevention, as well as feeding and medication. Cage used in generally still simple cage generally use a tin roof and side:, the concrete floor and the ground, and the walls are made of wood. Distance cage withbreeder house not too far of 7-10 meters. General beef cattle grazing and stabled at night night. The life span of the cage approximately 5-10 years. Feeding and drinking in the area of research done by the farmers themselves and assisted by the family as his wife and children. Breeders generally provide fodder grasses diarit of forage land around where they live. Diseases that often attack cattle in the area of research is into the wind. In addition there are other diseases like fever and intestinal worms.

Capital used by breeders sourced from its own capital, profit-sharing system or some assistance from the government. In general, farmers use their own capital because of the difficulty of obtaining capital. This capital issues can hamper the development of beef cattle business in Serdang Bedagai for livestock breeder will only be tried on a small scale only.

\subsection{Base Areas of Beef Cattle and Beef Cattle Population Density}

In Table 2. The results of the calculation Location quation (LQ) where wlayah-region has a value of LQ> 1 of 17 Districts in Serdang Bedagai only 8 Districts including the base area. Eight of the region is the District Serbajadi, Sipispis, Dolok Merawan, Tebing Tinggi Dolok Masihul, Bntang Bayu, Pegajahan, dan Pantai Cermin. Kecamatan Serbajadi. Subdistrict Serbajadi LQ has a value greater than the other sub-district (2.82), it can be said that the District Serbajadi have a total cattle population is relatively more than other districts and sub-district which is a non-base region in Serdang Bedagai by 9 districts.

Economic density seen in Table 2 that there is a solid 5 Districts belonging to the District Dolok Masihul, Serbajadi, Sipispis, Dolok Masihul and Bintang Bayu. While the District are classified as being contained 6 districts and sub-district which meliliki density rare 6 Districts. At the District's rare still be added the population in terms of the number of population in the wiliayah. While districts classified as being solid and keep as much as possible in the cattle population. Density effort. seen that there are two categories of very dense District of the District Dolok Merawan and Sipispis. There are 3 sub-district solid categories namely Sub Bintang Bayu, Serbajadi and Tebing Syahbandar. There are 9 subdistricts with the District Kotarih Medium category, Dolok Masihul, Tebing Tinggi, Bandar Khalipah, Sei Rampah, Perbaungan, Pantai Cermin and Silinda. There are 3 sub-district with the District's rare Category Tanjung Beringin, Sei Bamban, and Teluk Mengkudu. Thus, if in terms of arable land managed by farmers, the beef cattle population in Serdang Bedagai can still be improved. The area density looks very solid Districts with the criteria of the District Serbajadi. Districts with the existing criteria in the District 5 Dolok Masihul, Sipispis, Dolok Merawan, Pegajahan and Pantai Cermin. Districts with the Criteria were no 6-districts Bintang Bayu, Tebing Tinggi, Tebing Syahbandar, Bandar Khalipah, Sei Rampah and Perbaungan. Districts with the criteria of a rare 5districts Silinda, Tanjung Beringin, Sei Bamban, Teluk Mengkudu and Kotarih. 
Table 2. Value LQ and Livestock Density in Serdang Bedagai.

\begin{tabular}{lcccc}
\hline \multicolumn{1}{c}{ sub-district } & LQ & $\begin{array}{c}\text { Economic } \\
\text { density }\end{array}$ & $\begin{array}{c}\text { density } \\
\text { Areas }\end{array}$ & Farm \\
\hline Kotarih & 2,82 & 38.85 & 4,05 & 0.48 \\
Silinda & 2.52 & 24.91 & 3.72 & 0.19 \\
Bintang Bayu & 2.11 & 101.41 & 11.42 & 1.24 \\
Dolok Masihul & 2.03 & 147.61 & 30.64 & 0.61 \\
Sipispis & 1.9 & 190.91 & 42.3 & 4.76 \\
Serbajadi & 1.28 & 211.68 & 83.09 & 1.58 \\
Dolok Merawan & 1.24 & 297.58 & 42.7 & 48.58 \\
Tebing Tinggi & 1.13 & 66.28 & 14.98 & 0.48 \\
Tebing Syahbandar & 0.92 & 60.17 & 16.41 & 1.41 \\
Bandar Khalipah & 0.81 & 65.62 & 14.28 & 0.27 \\
Tanjung Beringin & 0.71 & 9.49 & 4.81 & 0.05 \\
Sei Rampah & 0.51 & 51.62 & 16.83 & 0.51 \\
Sei Bamban & 0.33 & 7.98 & 4.83 & 0.03 \\
Teluk Mengkudu & 0.3 & 13.23 & 8.3 & 0.08 \\
Perbaungan & 0.19 & 21.18 & 19.6 & 0.15 \\
Pegajahan & 0.14 & 92.32 & 27.16 & 0.46 \\
Pantai Cermin & 0.11 & 77.52 & 42.91 & 0.4 \\
\hline
\end{tabular}

Source: Primary Data Processing (BPS Serdang Bedagai 2016).

\subsection{Production of Agricultural Waste}

Production of fresh ingredients of agricultural waste in Serdang highest in the District Perbaungan Bedagai 114,323.55 tons / year, while the smallest waste lies in District of Dolok Merawan 406 tons / year, the overall amount of waste the potential of agriculture in Serdang Bedagai amounted to $702,962.95$ tons / year. Production of Dry Material (BK) from agricultural waste in Serdang Bedagai as much as $266,109.12$ tons, the highest production in the rice straw $139,866.55$ tons, followed by cassava leaves 53874.40 71053.71 tons and tons of corn straw. Production of agricultural waste by Protein Coarse (PK), overall waste production in Serdang Bedagai much as 25036.47 tons. PK production waste Sipispis highest in the District as much as 13798.68 tons.71.50 tonnes and TDN in Serdang Bedagai overall total of 129,987.20 tonnes.

\subsection{Feed Concentration Index, Capability and the index Agricultural Waste.}

In Table 3 it can be seen that the Feed Concentration Value Index (IKP), the largest in the District Sipispis by the number of IKP 6.62 with fresh material production amounted to $103,866.54$ tons, the lowest value contained in the District IKP Dolok Merawan of 0.01 with the production of fresh ingredients amounted to 107.07 tons. It can be seen carrying capacity of the agricultural waste of dry matter, crude protein and digestible nutrients in Serdang ST Bedagai of 116 904, 104319 and 82847 ST ST. The carrying capacity of agricultural waste in the District Serdang Bedagai able to accommodate and provide fodder for cattle population needs based on the needs of dry matter / year with the number of 116904 cattle. can be seen the value IDDLP high category No 6 subdistrict Subdistrict namely Silinda, Sipispis, Tanjung Beringin, Sei Bamban, Noni bay and Perbaungan which means at the sub-district has a high carrying capacity of waste is recommended for nemambah the number of animals kept. IDDLP medium category there are 4 Districts namely Sub Kotarih, Bandar Khalipah, Pegajahan, Pantai Cermin means the region can still be added the number of animals kept. IDDLP low category No 7 Bintang Bayu District of the District, Dolok Masihul, Serbajadi, Dolok Merawan, Tebing Tinggi, Tebing Syahbandar and Sei Rampah. 
Table 3. IKP, carrying capacity and index Agricultural waste in Serdang Bedagai Capability

\begin{tabular}{|c|c|c|c|c|c|c|c|}
\hline \multirow[t]{2}{*}{ sub-district } & \multirow{2}{*}{$\frac{\text { IKP }}{\text { IKP }}$} & \multicolumn{3}{|c|}{ Carrying ST } & \multicolumn{3}{|c|}{$\begin{array}{l}\text { Index } \\
\text { Agricultural Waste }\end{array}$} \\
\hline & & $\mathrm{BK}$ & PK & TDN & $\mathrm{BK}$ & PK & TDN \\
\hline Kotarih & 0.1 & 712.81 & 475.67 & 543.74 & 2.26 & 1.51 & 1.72 \\
\hline Silinda & 0.15 & 1046.56 & 634.53 & 686.3 & 4.96 & 3.01 & 3.25 \\
\hline Bintang Bayu & 0.06 & 418.62 & 672.79 & 399.6 & 0.38 & 0.62 & 0.37 \\
\hline Dolok Masihul & 1.05 & 7214.59 & 8436.19 & 5920.16 & 0.99 & 1.16 & 0.81 \\
\hline Sipispis & 6.62 & 45530.54 & 57494.49 & 40996.12 & 7,41 & 9.36 & 6,67 \\
\hline Serbajadi & 0.3 & 2070.68 & 1427.73 & 1242.40 & 0.49 & 0.34 & 0.29 \\
\hline Dolok Merawan & 0.01 & 46.93 & 80.98 & 45,57 & 0.01 & 0.02 & 0.01 \\
\hline $\begin{array}{l}\text { Tebing Tinggi } \\
\text { Tebing }\end{array}$ & 0.67 & 4599.41 & 2567.94 & 2467.56 & 1.68 & 0.94 & 0.9 \\
\hline syahbandar & 0.16 & 1087.37 & 728.93 & 647.12 & 0.55 & 0.37 & 0.33 \\
\hline Bandar Khalipah & 0.73 & 5011.61 & 2771.86 & 2682.88 & 3.03 & 1.67 & 1.62 \\
\hline Tanjung Beringin & 0.93 & 6427.50 & 3550.79 & 3438.75 & 18 & 9.95 & 9.63 \\
\hline Sei Rampah & 0.72 & 4981.35 & 3312.13 & 2887.84 & 1.49 & 0.99 & 0.86 \\
\hline Sei Bamban & 1.39 & 9534.30 & 5523.74 & 5347.31 & 27.32 & 15.83 & 15.32 \\
\hline Teluk Mengkudu & 0.82 & 5609.67 & 3084.55 & 2991.84 & 10.09 & 5.55 & 5.38 \\
\hline Perbaungan & 1.69 & 11643.55 & 6602.13 & 6314.10 & 5.32 & 3.02 & 2.88 \\
\hline Pegajahan & 0.58 & 4007.24 & 3089.84 & 2500.28 & 1.58 & 1.22 & 0.99 \\
\hline Pantai Cermin & 1.01 & 6961.61 & 3864.31 & 3735.58 & 2.02 & 1.12 & 1.08 \\
\hline
\end{tabular}

Source: Primary Data Processing (BPS Serdang Bedagai 2016).

3.8 The population of enhancing the capacity of Ruminant (KPPTR) and Beef Cattle Development Area

Table 4. Development Area Beef Cattle in Serdang Bedagai

\begin{tabular}{ccc}
\hline territory & Criteria & sub-district \\
\hline I & KPPTR (E) Positive, LQ $>$ 1Bintang Bayu, Pegajahan, Dolok Masihul, & Sipispis, Tebing Tinggi, \\
& & Pantai Cermin. \\
II & KPPTR (E) Positive, LQ < 1 Rampah, Kotarih, Silinda, Perbaungan, Teluk \\
& & Mengkudu, Tanjung Beringin \\
II & KPPTR (E) is negative, LQ $>1$ & Dolok Merawan \\
\hline
\end{tabular}

Source: Primary Data Processing (BPS Serdang Bedagai 2016).

The total value of the effective KPPTR (KPPTR (E)) is Serdang Bedagai 234884 ST. It shows that the Serdang Bedagai still great potential for the addition of niilai KPPTR ruminants such. However, in practice in the field need to consider several factors such as technical, social, cultural and skills of farmers in managing governance patterns cattle raising beef cattle. Spreading KPPTR value in each district varies greatly, the highest value in the DistrictSipispisKPPTRof52.907,46ST. Region I is the area with KPPTR value (E) is positive, LQ> 1 . This means that the group of districts in the region have sufficient availability of forage to offset the increase in the livestock population of KPPTR value (E) is. In addition the level of ownership of cattle in the district are relatively better than the rate of overall holdings of beef cattle in Serdang Bedagai. The second group is a group area with KPPTR value (E) is positive, LQ $<1$. This means that the sub-districts in this area groups have sufficient availability of forage to offset the increase in the livestock population of KPPTR value (E) 
is. But the level of ownership of beef cattle in the sub-districts, not as good as the level of overall ownership of beef cattle in Serdang Bedagai. Group III region is a group that has a value KPPTR region (E) is negative, LQ> 1. This means that the availability of forage in the sub group of this region have been optimally, even an excess amount of the beef cattle population KPPTR (E) is. Despite the availability of forage in this area is less and the group no longer possible to be increased cattle population of intersection, but the region has a group of beef cattle ownership levels in the districts are relatively better than the rate of overall holdings of beef cattle in Serdang Bedagai. even an excess amount of the beef cattle population KPPTR (E) is. Despite the availability of forage in this area is less and the group no longer possible to be increased cattle population of intersection, but the region has a group of beef cattle ownership levels in the districts are relatively better than the rate of overall holdings of beef cattle in Serdang Bedagai. even an excess amount of the beef cattle population KPPTR (E) is. Despite the availability of forage in this area is less and the group no longer possible to be increased cattle population of intersection, but the region has a group of beef cattle ownership levels in the districts are relatively better than the rate of overall holdings of beef cattle in Serdang Bedagai.

\subsection{Beef Cattle Development Strategy}

\subsection{1 region $I$}

LQ and KPPTR results of the analysis showed that the first region consisting of the District Serbajadi, Sipispis, Tebing Tinggi, Bintang Bayu, Pegajahan, Dolok Masihul and Pantai Cermin. Groups of this region have the potentials and constraints in the development of the region as a center of beef cattle production. Some alternative strategies based on SWOT matrix.

\section{9 .2 region $I I$}

The results of the analysis of LQ and KPPTR in region II consisting of the District Bandar Khalipah, Tebing Syahbandar, Sei Rampah, Kotarih, Silinda, Perbaungan, Teluk Mengkudu, Tanjung Beringin and Sei Bamban. This means that the level of ownership of cattle in this region is still below the level of the overall ownership of beef cattle in Serdang Bedagai. Although still below the level of ownership, but the region has the potential to feed supply. This is evidenced by KPPTR positive value.

\subsection{3 region II}

The results of the analysis of LQ and KPPTR in region III Dolok Merawan the District, the District's discount cattle ownership levels are quite high when compared to the level of overall kapemilikan beef cattle in Serdang Bedagai. This area is one area that has the facilities and infrastructure sufficient for the development of beef cattle, although the value of KPPTR showed negative results. Some alternative strategies based on SWOT matrix obtained.

\section{Conclusion}

Serdang Bedagai have the potential environmental good breeding. Climatic factors, the temperature and the humidity enough support in developing breeding beef cattle. Business Resource farms in Bedagai Serdang great potential in developing the beef cattle business. Opportunities increased capacity of 234632 cattle ST and high agricultural waste able to meet the needs of cattle feed, agricultural waste and carrying a high of 120901 ST (BK), 108767 ST (PK), and 85959 ST (TDN). Center area (Base) of cattle in Serdang Bedagai quite extensive, there are 8 districts of 17 kecmatan in Serdang Bedagai, of each - each region located in Serdang Bedagai has a strategy to develop beef cattle business.

\section{References:}

[1]Badan pusat statistik.2016.Serdang Bedagai Dalam Angka 2016. Serdang Bedagai.

[2]Balai Penelitian Peternakan. 1997. Analisis Potensi Wilayah di Jawa Barat. Bogor.

[3]Haerudin. 2004. Potensi dan Daya Dukung Limbah Pertanian sebagai Pakan Sapi Potong di Kabupaten Soppeng Sulawesi Selatan. Institut Pertanian Bogor, Bogor 
[4]Lasmanawati, N. 2006. Analisis SWOT pengembangan peternakan ruminansia berdasarkan potensi hijauan pakan mengunakan bahasa pemprograman Visual Basic 6.0. Skripsi. Fakultas Peternakan Institut Pertanian Bogor, Bogor.

[5]Nell, A. J. Dan Rollinson. 1974. The Requirement an Avaliability of Livestock Feed in Indonesia. UNDP project INS/72/009.

[6]Nutrional Research Council (NRC). 1984. Nutrient Requirement of Beef Cattle. Washington DC National Academy Press, United Stated of America.

[7]Rosida, I. 2006. Analisis potensi sumberdaya peternakan Kabupaten Tasikmalaya sebagai wilayah pengembangan ternak Sapi Potong. Skripsi. Fakultas Peternakan Institut Pertanian Bogor, Bogor.

[8]Syamsu, J. 2006. Limbah Tanaman Pangan sebagai Sumber Pakan Ruminansia Potensi Daya Dukung di Makassar. Yayasan Emulsi dan Dinas Peternakan, Sulawesi Selatan.

[9]UU Peternakan dan Kesehatan Hewan 2009. Undang - undang peternakan dan kesehatan hewan. 